\title{
Emerging MDR producing ESBL among Diarrhoegenic Esherichia coli from paediatric patients
}

\author{
Ashita A Pinto*, Yaser Siahbalaei, Arif Ali \\ From 2nd International Science Symposium on HIV and Infectious Diseases (HIV SCIENCE 2014) \\ Chennai, India. 30 January - 1 February 2014
}

\section{Background}

The beta lactam antibiotics are predominant therapeutic agents against a number of infectious diseases. The production of the enzyme beta lactamase by microbes which hydrolyses the beta lactam antibiotics is an important mechanism of resistance. This study aimed to determine prevalence, phenotypic patterns, and ESBLproduction status both phenotypic and genotypic for the CTX - M type ESBL in Escherichia coli (E.coli) isolated from Diarrhoeic children.

\section{Methods}

Two hundred thirty non repetitive stool samples were collected from 2 hospitals, one private and other government hospital in Delhi, NCR. E.coli was confirmed by $16 S$ rRNA analyses. Antibiotic susceptibility and phenotypic ESBL production were studied by disc diffusion and double disk synergy tests according to Clinical Laboratory Standards Institute guidelines. PCR was performed for the molecular detection of the CTX-M type ESBL.

\section{Results}

Out of 230, 215 were confirmed to be E.coli. Phenotypically $72.5 \%$ (156) showed the presence of ESBL of which 75\% (79) in private hospital samples and 70\% (77) in government hospital samples. PCR based molecular detection confirmed the presence of the $C T X-M$ gene among $65.6 \%$ (141) of the samples.

\section{Conclusion}

The high trends in the ESBL presence are alarming and urge means to cope with such ESBL E.coli strains.

\footnotetext{
* Correspondence: apintodelhi@gmail.com

Gene Expression Laboratory, Department of Biosciences, Jamia Millia Islamia, New Delhi, India
}

Cite this article as: Pinto et al.: Emerging MDR producing ESBL among

Submit your next manuscript to BioMed Central and take full advantage of:

- Convenient online submission

- Thorough peer review

- No space constraints or color figure charges

- Immediate publication on acceptance

- Inclusion in PubMed, CAS, Scopus and Google Scholar

- Research which is freely available for redistribution 